\title{
INFLUENCE OF VOLCANIC SCORIA ON MECHANICAL STRENGTH, CHEMICAL RESISTANCE AND DRYING SHRINKAGE OF MORTARS
}

\author{
A. AL-SWAIDANI ${ }^{1}$, S. ALIYAN ${ }^{2}$, N. ADARNALY ${ }^{3}$, B. HANNA ${ }^{4}$, E. DYAB $^{5}$
}

In the study, three types of cement have been prepared; one CEM I type (the control sample) and two blended cements: CEM II/A-P and CEM II/B-P (EN 197-1), each of them with three replacement levels of volcanic scoria: $(10 \%, 15 \%, 20 \%$ wt.) and $(25 \%, 30 \%, 35 \%$ wt. $)$, respectively. Strength development of mortars has been investigated at 2, 7, 28 and 90 days curing. Evaluation of chemical resistance of mortars containing scoria-based cements has been investigated through exposure to $5 \%$ sulphate and $5 \%$ sulphuric acid solutions in accordance with ASTM C1012 \& ASTM 267, respectively. Drying shrinkage has been evaluated in accordance with ASTM C596. Test results showed that at early ages, the mortars containing CEM II/B-P binders had strengths much lower than that of the control mortar. However, at 90 days curing, the strengths were comparable to the control mortar. In addition, the increase of scoria significantly improved the sulphate resistance of mortars. Further, an increase in scoria addition improved the sulphuric acid resistance of mortar, especially at the early days of exposure. The results of drying shrinkage revealed that the CEM II/B-P mortar bars exhibited a greater contraction when compared to the control mortar, especially at early ages. However, drying shrinkage of mortars was not influenced much at longer times.

Keywords: strength, chemical attack, drying shrinkage, blended cement, durability, natural pozzolan

\section{Introduction}

The use of natural pozzolan in the production of blended Portland cements makes important effects on physical, chemical, mechanical and durability properties of mortar and concrete (Cavdar and Yetgin, 2007; Ghrici et al., 2006; Hossain, 2009; Rodriguez-Camacho and UribeAfif, 2002; Senhadji et al., 2012; Turanli et al., 2005). In addition, since this material enters the cement production after a kiln process, it also provides important economical and ecological benefits (Mehta and Monteiro, 2006). According to (Mehta and Monteiro, 2006), the manufacture of one tonne of Portland cement (PC) clinker consumes energy of about 4 GJ, and releases nearly one tonne of $\mathrm{CO}_{2}$ to the atmosphere. For this reason, a particular attention was recently given to the exploitation of natural pozzolan, which is broadly abundant in Syria. More than $30,000 \mathrm{~km}^{2}$ of the country is covered by Tertiary and Quaternary-age volcanic rocks

\footnotetext{
${ }^{1}$ Faculty of Architectural Engineering, Arab International University (AIU), Damascus, Syria; e-mail: aydlswaidani@yahoo.fr; a-swaidani@aiu.edu.sy

${ }^{2}$ Syria Arab Organization for Standardization and Metrology (SASMO), Damascus, Syria

${ }^{3}$ General Organization for Cement and Building Materials, Damascus, Syria

${ }^{4}$ Faculty of Civil Engineering, al-Baath University, Homs, Syria

${ }^{5}$ Order of the Syrian Engineer, Damascus, Syria
} 
(General Establishment of Geology and Mineral Resources in Syria, 2011) in which scoria occupies an important volume with estimated reserves of more than 600 million tones (General Establishment of Geology and Mineral Resources in Syria, 2007). The cement produced in the country is almost of CEM I, although an addition of natural pozzolan up to $5 \%$ was frequently used in most local cement plants. Hence, less than 300,000 tonnes of scoria are only exploited annually (the annual production of Portland cement in Syria is about 6 million tonnes) (General Establishment for cement \& Building Materials, 2013).

In Syria, chemical attacks on concrete structures have caused serious damage to these concretes. According to previous studies (Ghrici et al., 2006; Ramezanianpour et al., 2010; Rodriguez-Camacho and Uribe-Afif, 2002), adding natural pozzolan led, through the pozzolanic reaction, to a refinement of the pore structure, resulting in a highly impermeable matrix. Further, a reduction in $\mathrm{Ca}(\mathrm{OH})_{2}$ led to reductions in the formation of gypsum and ettringite. In addition, drying shrinkage is inevitable phenomenon in all the cementitious products due to contraction of total mass upon the loss of moisture. This problem is more serious in such members whose surface area to volume ratio is large. The shrinkage is largely influenced by mineral additions when used as a partial cement replacement. According to Itim et al. (2011), adding natural pozzolans as a partial cement replacement involves an additional formation of CSH, which generates more shrinkage. Many researchers (Massazza and Costa, 1979; Mehta, 1981; Shannag and Yeginobali, 1995) showed that shrinkage of natural pozzolan-based cement was generally higher than that of ordinary Portland cement.

Although there are numerous studies on using natural pozzolan as a cement replacement, no detailed research was conducted in the past to investigate the potential use of volcanic scoria in the production of blended cements in Syria. The objective of this paper is to report a part of this ongoing research on the effect of different amount of volcanic scoria when adding as a cement replacement on the strength and some durability-related properties. Mechanical strength development, chemical attack and drying shrinkage have been particularly investigated in the study. Some chemical and physical properties of blended cements have also been reported. The study is of a particular importance not only for the country but also for other areas of similar geology, e.g. Harrat Al-Shaam, a volcanic field covering the total area of some 45,000 $\mathrm{km}^{2}$, third of which is located in the country. The rest is covering parts of Jordan and Saudi Arabia.

\section{Experimental procedure}

Scoria. The scoria used in the experiments was collected from a quarry, at $70 \mathrm{~km}$ southeast of Damascus as shown in Figure 1. The petrographic examination showed the scoria consists of amorphous glassy groundmass, vesicles, plagioclase and olivine with the following percentages (based on an optical estimate): $20 \%, 35 \%, 20 \%$ and $25 \%$, respectively. The scoria is dark black to blackish-grey in colour with some red-brown spots, mostly due to its iron oxides content. Figure 2 shows thin sections of the used scoria. The chemical analysis of scoria used in the study is summarized in Table 1 . This analysis was carried out by means of wet chemical analysis specified in EN 196-2(1989).

Cement samples. Three types of binder have been prepared, one plain Portland cement CEM I (the control sample), and two blended cements: CEM II/A-P and CEM II/B-P (EN 1971:2004), each of them with 3 replacement levels of scoria: (10\%,15\% and $20 \%$ wt.) and (25\%, $30 \%, 35 \%$ wt.), respectively. $5 \%$ of gypsum was added to all these cements. The clinker used for producing the binders was obtained from Adra Cement Plant, Damascus, Syria. 
Chemical analysis of clinker and gypsum is shown in Table 1. All binders were interground by a laboratory-grinding mill to a Blaine fineness of $3200 \pm 50 \mathrm{~cm}^{2} / \mathrm{g}$. All replacements were made by mass of cement. Table 2 shows the chemical, physical and mechanical properties of the binders produced. CEM I (the control sample) was designated as $\mathrm{C} 1$, whereas blended cements were designated according to the replacement level. For instance, $\mathrm{C} 2 / 10 \%$ and $\mathrm{C} 7 / 35 \%$ refer to the blended cements containing $10 \%$ and $35 \%$ wt. of scoria, respectively. In sulphate attack and drying shrinkage tests, sulphate-resisting Portland cement was employed for a comparison. It was designated as C8.

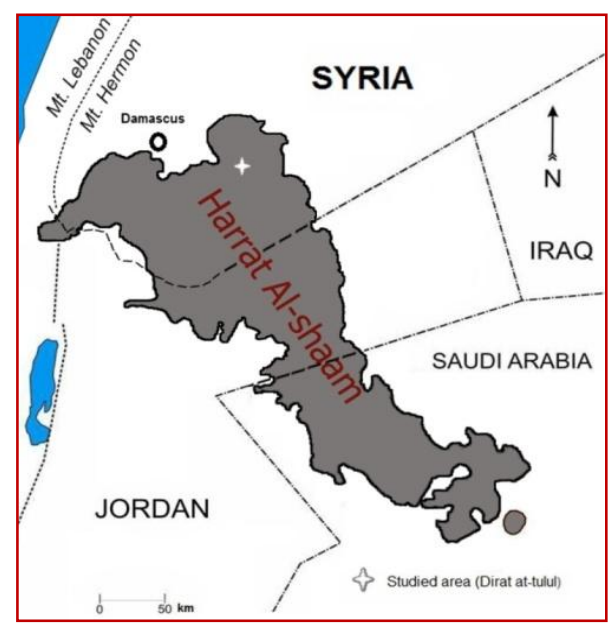

a

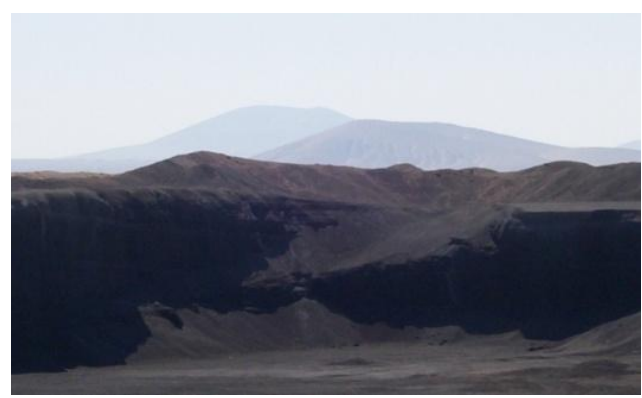

b

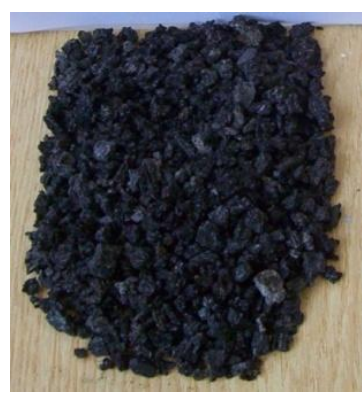

C

Figure 1. Map of Harrat Al-Shaam, photo of the studied quarry and the used scoria aggregate. a) Map of Harrat Al-Shaam and the studied area. b) The studied scoria quarry, some volcanic scoria cones are shown behind. c) The studied scoria aggregate

Mortar mixtures. Eight mortar mixtures have been prepared using the binders and sand meeting the requirements of ASTM C 778. In all mixtures, binder/sand ratio was kept constant as $1: 2.75$ by weight. Mixtures containing CEM I and SRPC were prepared with a w/b ratio of 0.485 . Mixtures containing the scoria-based blended cements were prepared by changing the w/b ratio in order to obtain a flow within \pm 5 of that of the CEM I mortar (measured in accordance with ASTM C 1437-03). The mortar specimens of all cements used in the 
experiments were prepared in a laboratory medium of $20 \pm 2{ }^{\circ} \mathrm{C}$ temperature and $50 \pm 5 \%$ relative humidity. After being kept in a wet cabinet for 24 hours, the mortar specimens were demolded and kept in water until they were tested.

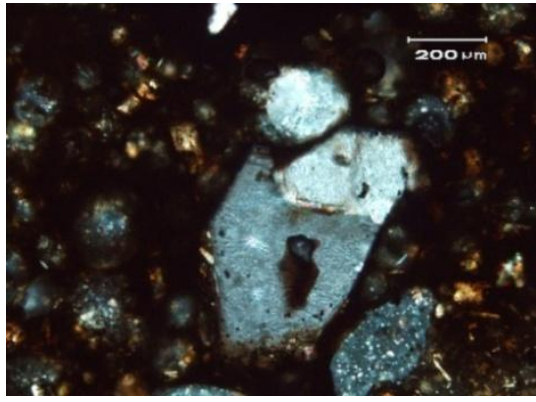

a

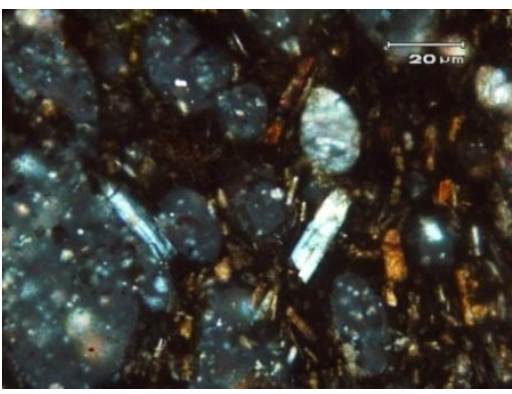

$\mathrm{b}$

Figure 2. Thin sections of the scoria. a) Microphenocryst of Olivine in volcanic glass matrix with vesicles, some of which are filled with white minerals. b) Microphenocrysts of elongated plagioclase in volcanic glass matrix with vesicles, some of which are filled with white minerals.

Mechanical properties. Compressive and flexural strength developments were determined on $40 \times 40 \times 160 \mathrm{~mm}$ prismatic specimens, in accordance with ISO 4012, after 2, 7, 28 and 90 days curing. The reported values represent the average of six readings for compressive strength test and the average of three readings for a flexural tensile strength test.

Chemical attack tests. Evaluation of the chemical resistance of mortars has been performed under two exposure conditions; sulphate and sulphuric acid attacks.

For sulphate attack test, prismatic mortar bars and cubes were cast from each mortar mixture in accordance with ASTM C 1012-04. The evaluation of sulphate attack resistance of mortars was performed in accordance with ASTM C 1012-04. Length measurements of the prepared prismatic specimens were performed at 1, 2, 3, 4, 8, 13, 15, 17, 26, 38 and 52 weeks after immersing the specimens into the sulphate $\left(5 \% \mathrm{Na}_{2} \mathrm{SO}_{4}\right)$ solution. The solution has been renewed four times throughout the test; at 8, 17, 26 and 38 weeks.

For the sulphuric acid attack test, a set of three cubes from each mixture was cast for each of curing age. The relative acid resistance was determined in accordance with ASTM C 267-01. The 28 and 90 days cured mortar cubes were immersed in $5 \%$ sulphuric acid solution for 100 days. The Plexiglas containers with immersed mortars were kept covered throughout the testing period to minimize the evaporation. At 2, 7, 14, 28, 56, 84 and 100 days of exposure, the mortar specimens were cleaned with distilled water, then the acid resistance was evaluated through measurement of the weight loss of the specimens determined as follows: Weight loss $(\%)=\left[\left(W_{1}-W_{\mathrm{t}}\right) / W 1\right] \times 100$, where $W_{1}$ is the weight $(\mathrm{g})$ of the specimens before immersion and $W_{\mathrm{t}}$ is the weight $(\mathrm{g})$ of cleaned specimens after $t$ day immersion. The average weight losses for each mortar cubes have been reported.

Drying shrinkage test. Specimens of $25 \times 25 \times 285 \mathrm{~mm}^{3}$ have been prepared from each binder type. Each specimen was fitted with stainless steel studs at both ends. After casting for 
$24 \mathrm{~h}$, the specimens were removed from the molds and cured in a lime-saturated water for 1 day. After the period of 3 days, the specimens were removed from the water, wiped with damp cloth, and measured immediately to determine the initial length of the mortar specimens. The mortar specimens were subsequently placed in air storage with a controlled temperature of $23 \pm 2{ }^{\circ} \mathrm{C}$ and a relative humidity of $50 \pm 5 \%$ as prescribed by ASTM C596. The drying shrinkage measurements were recorded at 7, 14, 21, 28, 56, 112, 180 and 360 days.

Table 1. Chemical composition of the used materials

\begin{tabular}{|l|c|c|c|}
\hline \multirow{2}{*}{$\begin{array}{l}\text { Chemical composition } \\
\text { by mass, \%) }\end{array}$} & $\begin{array}{c}|c| \\
\text { Volcanic } \\
\text { scoria* }\end{array}$ & Clinker & Gypsum \\
\cline { 2 - 4 } & 46.52 & 21.30 & 0.90 \\
\hline $\mathrm{SiO}_{2}$ & 13.00 & 4.84 & 0.07 \\
\hline $\mathrm{Al}_{2} \mathrm{O}_{3}$ & 11.40 & 3.99 & 0.10 \\
\hline $\mathrm{Fe}_{2} \mathrm{O}_{3}$ & 10.10 & 65.05 & 32.23 \\
\hline $\mathrm{CaO}$ & - & 2.1 & - \\
\hline $\mathrm{CaO}$ & 9.11 & 1.81 & 0.20 \\
\hline $\mathrm{MgO}_{\mathrm{Sg}}$ & 0.27 & 0.25 & 45.29 \\
\hline $\mathrm{SO}_{3}$ & 2.58 & - & 21.15 \\
\hline $\mathrm{Loss}_{\mathrm{n}}$ on ignition & 2.14 & 0.60 & - \\
\hline $\mathrm{Na}_{2} \mathrm{O}$ & 0.77 & 0.28 & - \\
\hline $\mathrm{K}_{2} \mathrm{O}$ & $<0.1$ & 0.05 & - \\
\hline $\mathrm{Cl}^{-}$ & 79 (at 7 days) & & \\
\hline Pozzolan activity index (ASTM C 618) $^{85}$ (at 28 days) & & \\
\hline
\end{tabular}

$* \mathrm{SiO}_{2 \text { (reactive) }}=42.22 \%$ (determined in accordance with EN 196-2)

\section{Results \& discussion}

Properties of volcanic scoria and blended cements. As seen from Table 1 , the volcanic scoria is considered a suitable material to be used as natural pozzolan. It satisfied the standards requirements for such a material by having the sum of $\mathrm{SiO}_{2}, \mathrm{Al}_{2} \mathrm{O}_{3}$ and $\mathrm{Fe}_{2} \mathrm{O}_{3}$ of more than $70 \%$, the $\mathrm{SO}_{3}$ content of less than $4 \%$ and the loss on ignition of less than $10 \%$ (ASTM C61801). $\mathrm{SiO}_{2 \text { reactive }}$ content is more than $25 \%$, as well (EN 197-1:2004). In addition, it has a strength activity index with Portland cement higher than the values specified in ASTM C618-04. The chemical and physical properties of volcanic scoria-based blended cements are also in conformity with the standards requirements (ASTM 595-01). Their contents of $\mathrm{MgO}$ and $\mathrm{SO}_{3}$ are less than $6 \%$ and $4 \%$, respectively. The loss on ignition is also less than $5 \%$ as specified in ASTM C595-01. Setting time and soundness values meet the limits specified in ASTM C595, for all binder types.

Mechanical properties of mortars. When natural pozzolans are used as a cement replacement the pozzolanic reactions will take place. Generally, the pozzolanic reaction can be defined as the chemical reaction between the amorphous silica, which is a major component of the pozzolan, and $\mathrm{CH}$ formed from the hydration of calcium silicates. The principal reaction is 
$\mathrm{CH}($ Portlanite $)+\mathrm{S}$ (reactive silica) $+\mathrm{H}($ Water $) \rightarrow \mathrm{C}-\mathrm{S}-\mathrm{H}$ (Calcium silicate hydrates)

The composition of C-S-H is not very different from that formed in regular hydration, although generally the C/S molar ratio is slightly lower (Mindess et al., 2003). The pozzolanic reaction is slow, portlandite-consuming and very efficient in filling up capillary spaces (Mehta and Montiero, 2006).

The results of compressive strength test are summarized in Table 3. As expected, the compressive strength of the mortar increases with a curing time, with a high rate of strength gains at early ages, which gradually decreases at longer ages. Plain cement mortar specimens have higher compressive strengths at any age when compared with volcanic scoria-based cement mortars. The compressive strength at 7 days decreases from 30.57 to $19.99 \mathrm{MPa}$ when CEM I and CEM II/B-P with $35 \%$ of scoria were used, respectively. The curing of mortars containing $35 \%$ of scoria gave the compressive strength equal to only $66 \%$ of that of CEM I specimens. This could be explained by the slowness of the pozzolanic reaction between the glassy phase in scoria and the $\mathrm{CH}$ released during the cement hydration (Mindess et al., 2003). However, due to the continuation of this reaction and the formation of the secondary $\mathrm{C}-\mathrm{S}-\mathrm{H}$, a greater degree of hydration is achieved resulting in the strengths after 90 days curing which are comparable to those of CEM I specimens. In addition, the results obtained from the flexural test showed, as displayed in Figure 3, a similar trend to that of the compressive strength. The correlation between the compressive strength and the flexural strength for the entire population of test results is shown in Figure 4. The relation obtained is $f_{\mathrm{t}}=0.92\left(f_{c}\right)^{0.56}$ with the correlation factor of 0.95. This relation seems to fit well the relation proposed by (ACI 363R: 1992).

\section{Chemical resistance of mortars}

Sulphate attack. Sulphate attack on cement mortar is actually a rather complex process that may involve all of the hydration products produced by Portland cement. The damage caused by sulphate attack may involve cracking and expansion of mortar as a whole, as well as softening and disintegration of cement paste (Mindess et al., 2003). Cements with a high $\mathrm{C}_{3} \mathrm{~A}$ content will be subject to sulphoaluminate corrosion in which ettringite is formed as displayed in Eq. (2) (Mindess et al., 2003; Skalny et al., 2002)

$$
\mathrm{C}_{4} \mathrm{AS̆}_{12} \text { (Monosulfate) }+2 \mathrm{CS}^{\mathrm{S}} \mathrm{H}_{2}(\text { Gypsum })+16 \mathrm{H} \text { (Water) } \rightarrow \mathrm{C}_{6} \mathrm{AS}_{3} \mathrm{H}_{32} \text { (Ettringite) }
$$

This type of corrosion is initiated by the reaction between sulphate ions and calcium hydroxide $(\mathrm{CH})$ :

$$
\mathrm{CH}(\text { Calcium hydroxide })+\mathrm{SO}_{4}{ }^{2-}{ }_{\text {(aq) }}(\text { Sulfate ion }) \rightarrow \mathrm{CS}^{5} \mathrm{H}_{2}(\text { Gypsum })+2 \mathrm{OH}^{-}(\mathrm{aq})
$$

This reaction can be described as gypsum corrosion. Both reactions are accompanied by an expansion in solid volume causing internal stresses and ultimately leads to cracking (Mindess et al. 2003). 
Influence of volcanic scoria on mechanical strength, chemical resistance and drying shrinkage of mortars

Table 2. Chemical, physical and mechanical properties of plain and blended cements

\begin{tabular}{|c|c|c|c|c|c|c|c|c|c|}
\hline \multirow{2}{*}{$\begin{array}{l}\text { Chemical } \\
\text { composition (\%) }\end{array}$} & \multicolumn{9}{|c|}{ Chemical properties of plain and blended cements } \\
\hline & & $\begin{array}{c}\text { C1/ } \\
\text { CEMI }\end{array}$ & $\begin{array}{c}\mathrm{C} 2 / 10 \\
\%\end{array}$ & $\begin{array}{c}\mathrm{C} 3 / 15 \\
\%\end{array}$ & $\begin{array}{c}\mathrm{C} 4 / 20 \\
\%\end{array}$ & $\begin{array}{c}\mathrm{C} 5 / 2 \\
5 \% \\
\end{array}$ & $\begin{array}{c}\mathrm{C} 6 / 30 \\
\%\end{array}$ & $\begin{array}{c}\mathrm{C} 7 / 35 \\
\%\end{array}$ & $\begin{array}{c}\text { C8/ } \\
\text { SRPC }\end{array}$ \\
\hline $\mathrm{SiO}_{2}$ & & 20.69 & 21.59 & 22.35 & 23.25 & 24.00 & 24.33 & 24.61 & 20.72 \\
\hline $\mathrm{Al}_{2} \mathrm{O}_{3}$ & & 5.09 & 5.20 & 5.68 & 5.73 & 6.55 & 6.80 & 7.39 & 4.33 \\
\hline $\mathrm{Fe}_{2} \mathrm{O}_{3}$ & & 4.23 & 4.75 & 4.79 & 5.15 & 5.43 & 5.47 & 6.31 & 5.79 \\
\hline $\mathrm{CaO}$ & & 60.62 & 58.21 & 55.18 & 53.05 & 50.30 & 48.00 & 44.84 & 61.69 \\
\hline $\mathrm{MgO}$ & & 2.46 & 2.66 & 3.23 & 3.39 & 3.87 & 4.11 & 4.63 & 1.21 \\
\hline $\mathrm{SO}_{3}$ & & 2.26 & 2.31 & 2.20 & 2.20 & 2.30 & 2.26 & 2.55 & 2.13 \\
\hline Loss on ignition & & 1.41 & 1.40 & 1.43 & 1.37 & 1.47 & 1.48 & 1.60 & 2.90 \\
\hline $\mathrm{Na}_{2} \mathrm{O}$ & & 0.60 & 0.71 & 0.83 & 0.94 & 1.07 & 1.16 & 1.31 & 0.21 \\
\hline $\mathrm{K}_{2} \mathrm{O}$ & & 0.35 & 0.39 & 0.43 & 0.46 & 0.50 & 0.53 & 0.57 & 0.19 \\
\hline $\mathrm{Cl}^{-}$ & & 0.023 & 0.021 & 0.022 & 0.019 & 0,018 & 0.019 & 0.019 & 0.022 \\
\hline Insoluble Residue & & 1.03 & 1.58 & 2.09 & 2.51 & 3.48 & 4.08 & 5.33 & 0.36 \\
\hline \multirow{5}{*}{$\begin{array}{l}\text { Content of clinker } \\
\text { minerals (from } \\
\text { PC) in the } \\
\text { mixtures of } \\
\text { blended cements } \\
\text { «Based on Bogue } \\
\text { composition » }\end{array}$} & $\mathrm{C} 3 \mathrm{~S}$ & 53.36 & 50.55 & 47.74 & 44.94 & 42.13 & 39.32 & 36.51 & 50.16 \\
\hline & $\mathrm{C} 2 \mathrm{~S}$ & 17.76 & 16.82 & 15.89 & 14.95 & 14.02 & 13.08 & 12.15 & 21.58 \\
\hline & $\mathrm{C} 3 \mathrm{~A}$ & 5.78 & 5.47 & 5.17 & 4.86 & 4.56 & 4.26 & 3.95 & 1.69 \\
\hline & $\mathrm{C} 4 \mathrm{AF}$ & 11.53 & 10.93 & 10.32 & 9.71 & 9.11 & 8.50 & 7.89 & 17.60 \\
\hline & $\begin{array}{l}\mathrm{C} 3 \mathrm{~S} / \\
\mathrm{C} 2 \mathrm{~S}\end{array}$ & 3.0 & 3.0 & 3.0 & 3.0 & 3.0 & 3.0 & 3.0 & 2.32 \\
\hline & \multicolumn{9}{|c|}{ Physical properties of plain and blended cements } \\
\hline Specific gravity & & 3.13 & 3.09 & 3.05 & 3.02 & 2.99 & 2.98 & 2.96 & \\
\hline $\begin{array}{l}\text { Initial setting time } \\
(\mathrm{min})\end{array}$ & & 151 & 153 & 153 & 153 & 152 & 153 & 158 & \\
\hline $\begin{array}{l}\text { Final setting time } \\
(\mathrm{min})\end{array}$ & & 178 & 179 & 180 & 180 & 179 & 181 & 188 & \\
\hline Water demand $(\%)$ & & 25.1 & 25.2 & 25.2 & 25.4 & 25.4 & 25.4 & 25.5 & \\
\hline Soundness (mm) & & 0.6 & 0.7 & 0.8 & 0.8 & 0.9 & 1.1 & 0.9 & \\
\hline $\begin{array}{l}\text { Residue on } 45 \mu \mathrm{m} \\
\text { sieve }(\%)\end{array}$ & & 13.6 & 14.3 & 14.8 & 15.2 & 16.1 & 17.0 & 17.9 & \\
\hline $\begin{array}{l}\text { Residue on } 90 \mu \mathrm{m} \\
\text { sieve }(\%)\end{array}$ & & 6.4 & 6.2 & 6.4 & 6.5 & 6.7 & 6.9 & 6.8 & \\
\hline
\end{tabular}


Table 3. Compressive strength of mortars

\begin{tabular}{|l|c|c|c|c|}
\hline \multirow{2}{*}{ Sample } & \multicolumn{4}{|c|}{ Compressive strength* (MPa)-Normalized } \\
\cline { 2 - 5 } & 2 days & 7 days & 28 days & 90 days \\
\hline C1/CEM I (Control) & $15.4-100 \%$ & $30.57-100 \%$ & $45.6-100 \%$ & $54.48-100 \%$ \\
\hline C2/10\% & $14.62-95 \%$ & $29.33-96 \%$ & $44.19-97 \%$ & $53.61-98 \%$ \\
\hline C3/15\% & $13.9-90 \%$ & $27.06-89 \%$ & $42.31-93 \%$ & $52.66-97 \%$ \\
\hline C4/20\% & $13.59-88 \%$ & $25.43-83 \%$ & $40.62-89 \%$ & $52.05-96 \%$ \\
\hline C5/25\% & $12.54-81 \%$ & $23.46-77 \%$ & $37.03-81 \%$ & $51.3-94 \%$ \\
\hline C6/30\% & $11.07-72 \%$ & $21.26-70 \%$ & $33.74-74 \%$ & $49.35-91 \%$ \\
\hline C7/35\% & $10.09-66 \%$ & $19.99-65 \%$ & $30.56-67 \%$ & $47.57-87 \%$ \\
\hline
\end{tabular}

* Standard deviation values ranged from 0.19 to $0.32 \mathrm{MPa}$ for strength results of all cement mortars

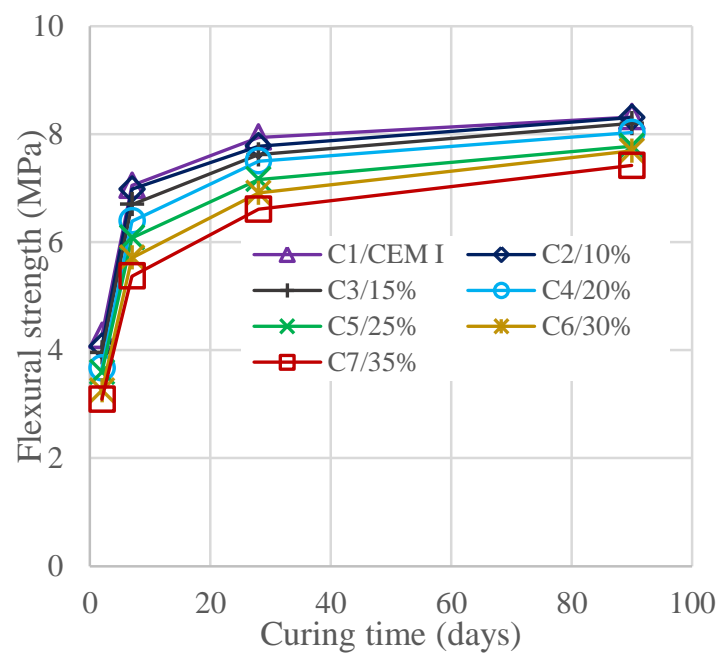

Figure 3. Development of flexural strength with curing time

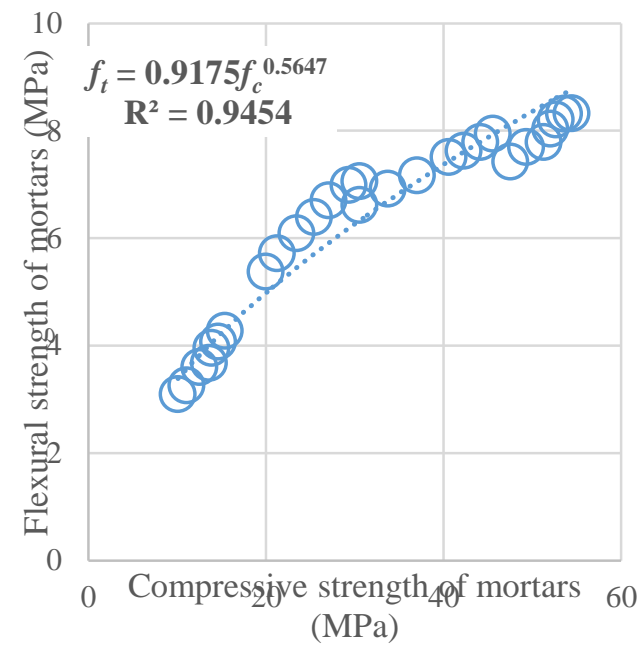

Figure 4. Correlation between compressive and flexural strength of mortars

The results of the expansion test of bars immersed in $5 \% \mathrm{Na}_{2} \mathrm{SO}_{4}$ solution for up to 52 weeks are shown in Figure 5. It was clearly seen from Figure 5, the use of scoria reduced expansion of the mortar bars. This reduction in the expansion increased with the increase in a scoria replacement level. These results were similar to those of other studies in which pozzolanic materials were used as cement replacements to improve sulphate resistance (Irassar et al., 2000; Tangchirapat et al., 2009). It should be also noted that the amount of expansion for SRPC mortar bars was very similar to that of CEM II/B mortar bars. At 26 and 52 weeks, the amount of expansion of the CEM II/B mortar bars ranged from $0.10 \%$ to $0.11 \%$ and from $0.18 \%$ to $0.19 \%$, respectively, whereas the expansion of SRPC was $0.09 \%$ and $0.16 \%$, respectively. This was despite the lack of $\mathrm{C}_{3} \mathrm{~A}$ in SRPC. The slightly elevated expansion noted in SRPC used in the study, which made it unsuitable for severe exposure, is possibly because the hydrated SRPC cement in SRPC mortars contains portlandite and $\mathrm{C}_{4} \mathrm{AF}$ in large proportions 
when compared to the CEM II/B mortars. These results confirmed earlier findings that the presence of $\mathrm{C}_{3} \mathrm{~A}$ is not the only cause of expansion due to sulphate attack (Cao et al., 1997; Tangchirapat et al., 2009).

According to ACI Committee 201, ettringite formation derived from ferroaluminate phase has also been assumed as a potential sulphate deterioration problem. The improvement of sulphate resistance by adding scoria as a cement replacement can be mainly explained by the pore size refinement, the removal of lime by the pozzolanic reaction of scoria with the lime liberated during cement hydration and the $\mathrm{C}_{3} \mathrm{~A}$ dilution as reported by Al-Amoudi (2002), Al-Dulaijan et al. (2003), Hooton and Emery (1990) and Irassar et al. (2000). The pore size refinement reduced the permeability of the paste, thus limiting the ingress of sulphate ions (Irassar et al., 2000). In terms of cement composition, $\mathrm{C}_{3} \mathrm{~A}$ is the main compound involving sulphate resistance, whereas $\mathrm{C}_{4} \mathrm{AF}$, an alumina-bearing phase, and $\mathrm{CH}$ released from silicates hydration can also affect the sulphate resistance of low $\mathrm{C}_{3} \mathrm{~A}$ Portland cements (Gonzalez and Irassar 1997). On the other hand, the $C_{3} S$ content was considered an important parameter on sulphate resistance of PC, too (Irassar et al. 2000). It can be noted that for CEM I of about $6 \%$ $\mathrm{C}_{3} \mathrm{~A}$ content, blending with $25 \%$ scoria content or more usually resulted in a performance similar to that of SRPC. This result is similar to that reported by Lawrence (1990).

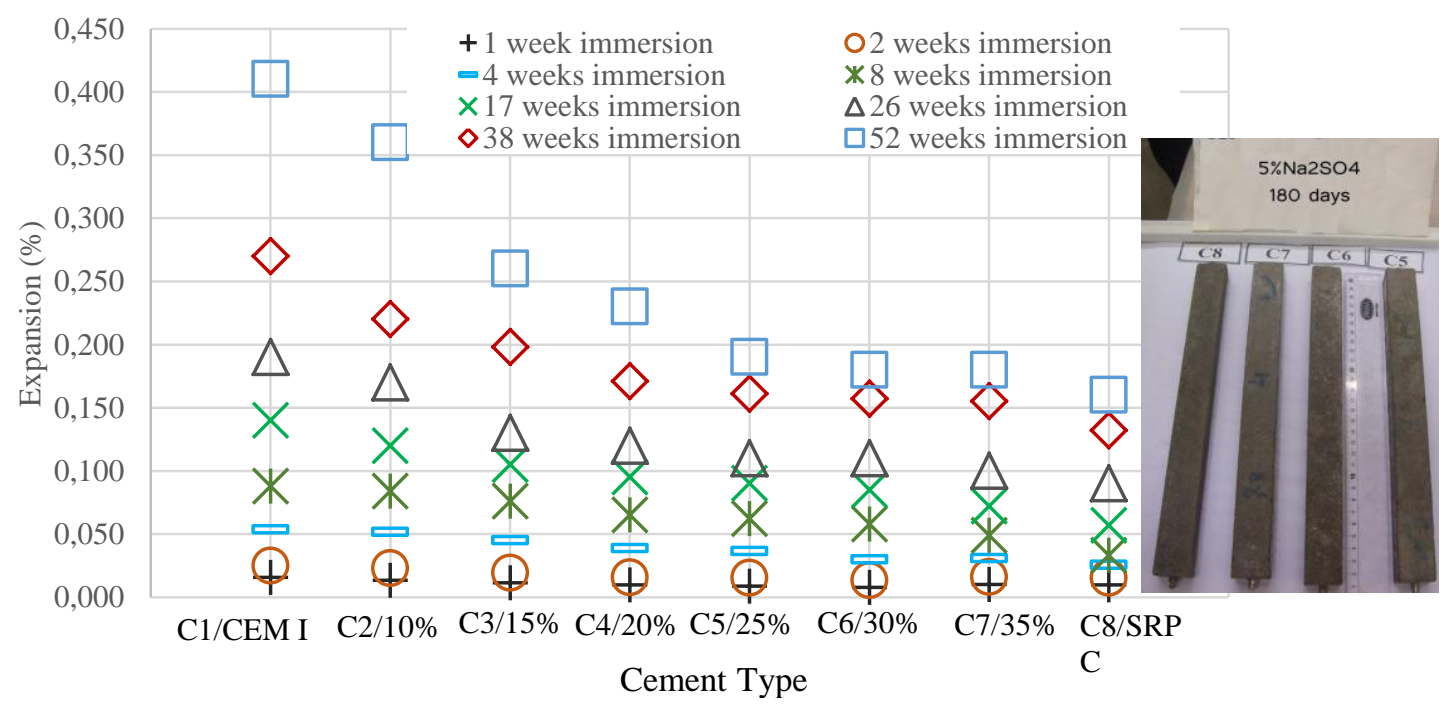

Figure 5. Length changes over time of prismatic mortars immersed in $5 \% \mathrm{Na}_{2} \mathrm{SO}_{4}$

Sulphuric acid attack. Sulphuric acid attack is very damaging to mortar as it combines an acid attack and a sulphate attack (Attiogbe \& Rizkalla 1988). At the first stage, deterioration of $\mathrm{Ca}(\mathrm{OH})_{2}$ results in an expansive gypsum formation. The gypsum then reacts with $\mathrm{C}_{3} \mathrm{~A}$ in aqueous environment and forms a more expansive product called ettringite. These very expansive compounds cause internal pressure in the mortar, which leads to the formation of cracks (Monteny et al. 2000), and the transformation of the mortar into a mushy or a noncohesive mass (Monteny et al. 2001). Sulphuric acid may also cause the decalcification of Calcium silicate hydrates $\mathrm{C}-\mathrm{S}-\mathrm{H}$ and will ultimately transform the C-S-H into amorphous hydrous silica. The following equations express these reactions (Monteny et al. 2000): 
Influence of volcanic scoria on mechanical strength, chemical resistance and drying shrinkage of mortars

$$
\begin{aligned}
& \mathrm{Ca}(\mathrm{OH})_{2}+\mathrm{H}_{2} \mathrm{SO}_{4} \rightarrow \mathrm{CaSO}_{4} \cdot 2 \mathrm{H}_{2} \mathrm{O} \text { (Gypsum) } \\
& 3\left(\mathrm{CaSO}_{4} \cdot 2 \mathrm{H}_{2} \mathrm{O}\right)+3 \mathrm{CaO} \cdot \mathrm{Al}_{2} \mathrm{O}_{3} \cdot 12 \mathrm{H}_{2} \mathrm{O}+14 \mathrm{H}_{2} \mathrm{O} \rightarrow 3 \mathrm{CaO} \cdot \mathrm{Al}_{2} \mathrm{O}_{3} \cdot 3 \mathrm{CaSO}_{4} \cdot 32 \mathrm{H}_{2} \mathrm{O}_{3} \text { (Ettringite) }
\end{aligned}
$$

$$
\mathrm{CaO} . \mathrm{SiO}_{2} .2 \mathrm{H}_{2} \mathrm{O}+\mathrm{H}_{2} \mathrm{SO}_{4} \rightarrow \mathrm{CaSO}_{4}+\mathrm{Si}(\mathrm{OH})_{4}(\text { Hydrous silica })+\mathrm{H}_{2} \mathrm{O}
$$

The white gypsum, which covers the surface of mortar, can potentially lead to the blocking of pores on the surface, leading to a slower rate of attack initially. However, this effect lasts only temporarily (Biczok, 1967).

The resistance to sulphuric acid solution was measured by means of the weight loss of the mortar cubes. Table 4 and Figure 6 show the weight loss of 28 and 90 days cured mortar cubes immersed in $5 \% \mathrm{H}_{2} \mathrm{SO}_{4}$ solutions, respectively. The weight loss is considered as a function of time. As expected, the sulphuric acid resistance of mortars improved with increasing the replacement level of volcanic scoria. This improvement of acid resistance was higher at early ages and decreased with increasing the immersion time. Beyond 28 days of exposure, slight improvements in the sulphuric acid resistance have been found. For instance, weight loss in 90 days cured mortars dropped from $34.8 \%$ (CEM I) to $29.4 \%$ (C7/35 \%) after 28 days of exposure to $5 \% \mathrm{H}_{2} \mathrm{SO}_{4}$.

The better performance of volcanic scoria-based cements can be due to the pozzolanic reaction (Cao et al., 1997; Aydin et al., 2007). This reaction between volcanic scoria and calcium hydroxide liberated during the hydration of cement (Aydin et al., 2007), led to a refinement of the pore structure resulting in a highly impermeable matrix as reported by Aydin et al. (2007) and Cao et al. (1997). This was also confirmed by the results of porosity measurements, which were conducted on $75 \mathrm{~mm}(\mathrm{D}) \times 150 \mathrm{~mm}(\mathrm{H})$ concrete cylinders using vacuum saturation method in accordance with RILEM CPC 11.3, (1984). The volcanic-scoria based concretes demonstrated a lower porosity as compared to the control concrete mix. For instance, the reduction in the porosity of C5/25\%-based concrete was about $20 \%$ and $45 \%$ as compared with CEM I-based concrete after 28 and 90 days curing, respectively (Unpublished data). In addition, results of concrete permeability in terms of depth of water penetration carried out as per the standard EN 12390-8 had a similar trend to that of porosity measurements (al-Swaidani et al., 2015).

Furthermore, the pozzolanic reaction fixes $\mathrm{Ca}(\mathrm{OH})_{2}$, which is usually the most vulnerable product of hydration of cement in so far as acid attack is concerned (Neville, 2011).

Contrary to expectation, the weight loss of SRPC mortars was very similar to that of CEM I mortars under similar conditions. This is possibly because the hydrated SRPC and CEM I mortars both contain portlandite and calcium silicates in large proportions. This was in agreement with results of Fattuhi and Hughes (1988). It should be also noted that after 100 days of exposure to sulphuric acid, SRPC and, to a smaller degree, CEM I mortar cubes showed a surface layer of brown colour. This brown-coloured layer, which is probably composed of ferric oxides (Pavlik, 1994), can be attributed to the higher content of $\mathrm{C}_{4} \mathrm{AF}$ in both cements. Further, sulphuric acid attack on mortars was associated with erosion and softening due to leaching of Ca and decalcification of C-S-H (Cao et al., 1997). 
Table 4. Weight losses of 28 days-cured mortars immersed in sulphuric acid solution

\begin{tabular}{|l|c|c|c|c|c|c|c|}
\hline \multirow{2}{*}{ Cement type } & \multicolumn{7}{|c|}{ Immersion time (days)-Weight loss (\%) } \\
\cline { 2 - 8 } & 2 & 7 & 14 & 28 & 56 & 84 & 100 \\
\hline C1/CEMI & 3.98 & 14.91 & 25.36 & 34.70 & 39.84 & 41.25 & 41.29 \\
\hline C2/10 \% & 3.41 & 14.17 & 25.27 & 34.19 & 39.45 & 40.97 & 41.09 \\
\hline C3/15\% & 3.03 & 13.86 & 24.50 & 34.06 & 39.24 & 40.78 & 40.89 \\
\hline C4/20\% & 2.67 & 13.28 & 23.99 & 33.74 & 39.04 & 39.68 & 39.84 \\
\hline C5/25\% & 1.10 & 10.80 & 22.47 & 32.94 & 38.51 & 39.53 & 39.62 \\
\hline C6/30\% & 0.92 & 9.58 & 20.34 & 31.94 & 36.77 & 38.84 & 39.19 \\
\hline C7/35\% & 0.87 & 4.97 & 18.47 & 29.51 & 35.70 & 37.71 & 38.40 \\
\hline C8/SRPC & 5.82 & 15.38 & 25.82 & 35.08 & 39.30 & 40.13 & 40.52 \\
\hline
\end{tabular}

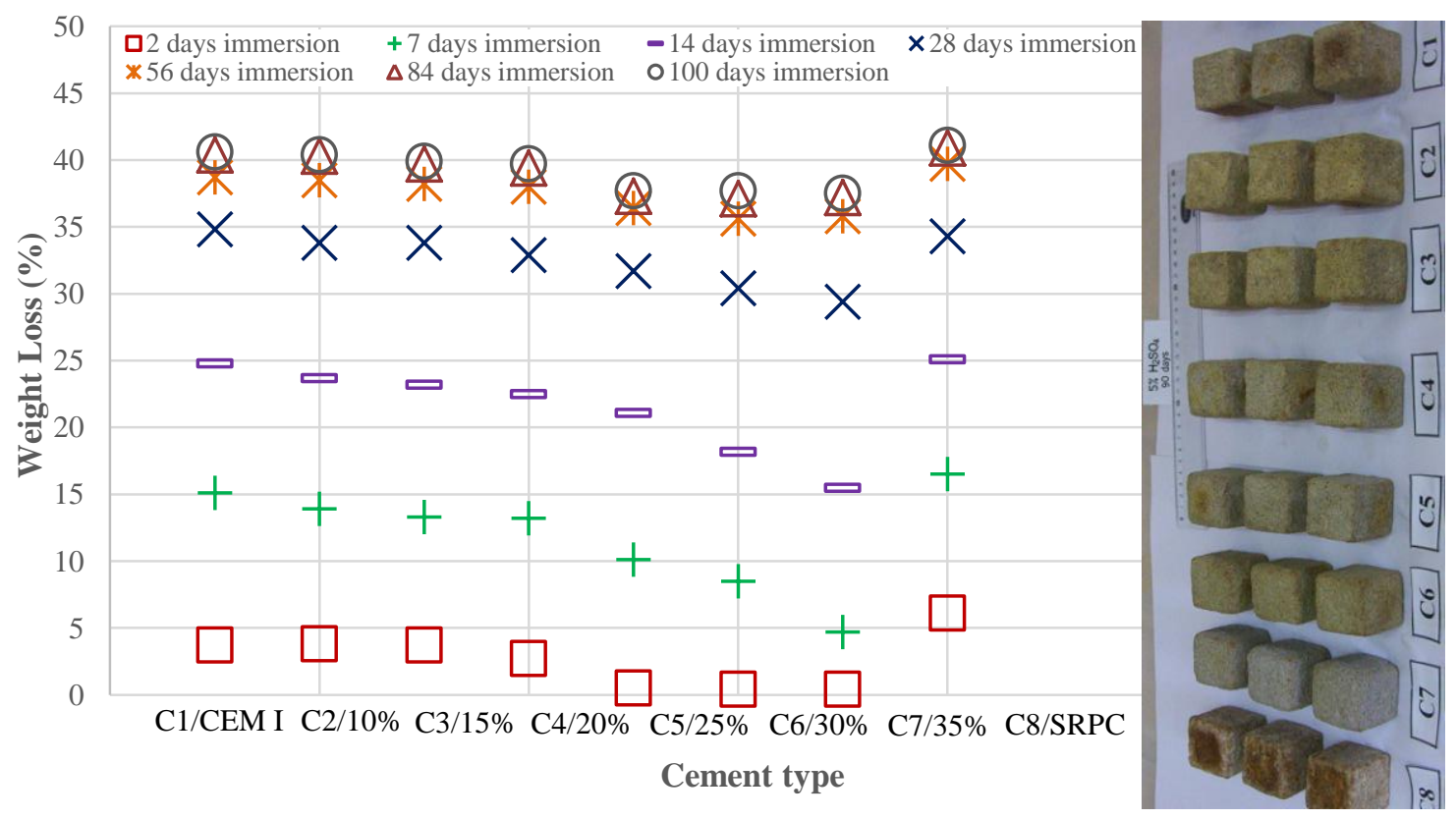

Figure 6. Weight losses over time of 90 days-cured mortars exposed to $5 \% \mathrm{H}_{2} \mathrm{SO}_{4}$

Drying shrinkage. Drying shrinkage represents the strain caused by the loss of water from the hardened material. The shrinkage is believed to originate in the C-S-H and its associated porosity (Mindess et al., 2003).

Figure 7 shows the results of drying shrinkage of scoria-based cement mortars. The results obtained agreed with the results published in the literature (Massazza and Costa, 1979; Mehta, 1981; Shannag and Yeginobali, 1995). The drying shrinkage developed rapidly at an early stage, with approximately $70 \%$ of the maximum shrinkage occurring during the first 28 days. The drying shrinkage curve patterns agreed with the observations reported by (Barr et al., 2003). At 360 days, the drying shrinkage values were found similar for all binder types. These drying shrinkage values agreed with those reported in the literature (Haque and Kayali, 1998; 
Massazza, 2006; Mehta, 1987). It is clearly seen from Figure 7 that all scoria-based mortars exhibited shrinkage values higher than the control mortar at the early ages. However, the difference becomes marginal from 28 days of drying onward. The increase of drying shrinkage with an increase of the cement replacement level which was clearly noted, especially at early ages, might be due to (i) the pozzolanic reaction which generates an additional CSH resulting in the decrease in spacing of CSH particles; (ii) the transportation of large pores into fine pores what is called "pore size refinement". Its formation increases the capillary tension (Meddah and Tagnit-Hamou, 2009; Rao, 2000; South, 2009; Touttanji and Bayasi, 1999); (iii) the higher water demand of scoria-based cements (South, 2009) as noted in Table 2; (iv) the much more porous microstructure of scoria (Massazza, 1993), as seen in Figure 2. However, this increase was much lower than the maximum $0.03 \%$ allowed by ASTM C618.

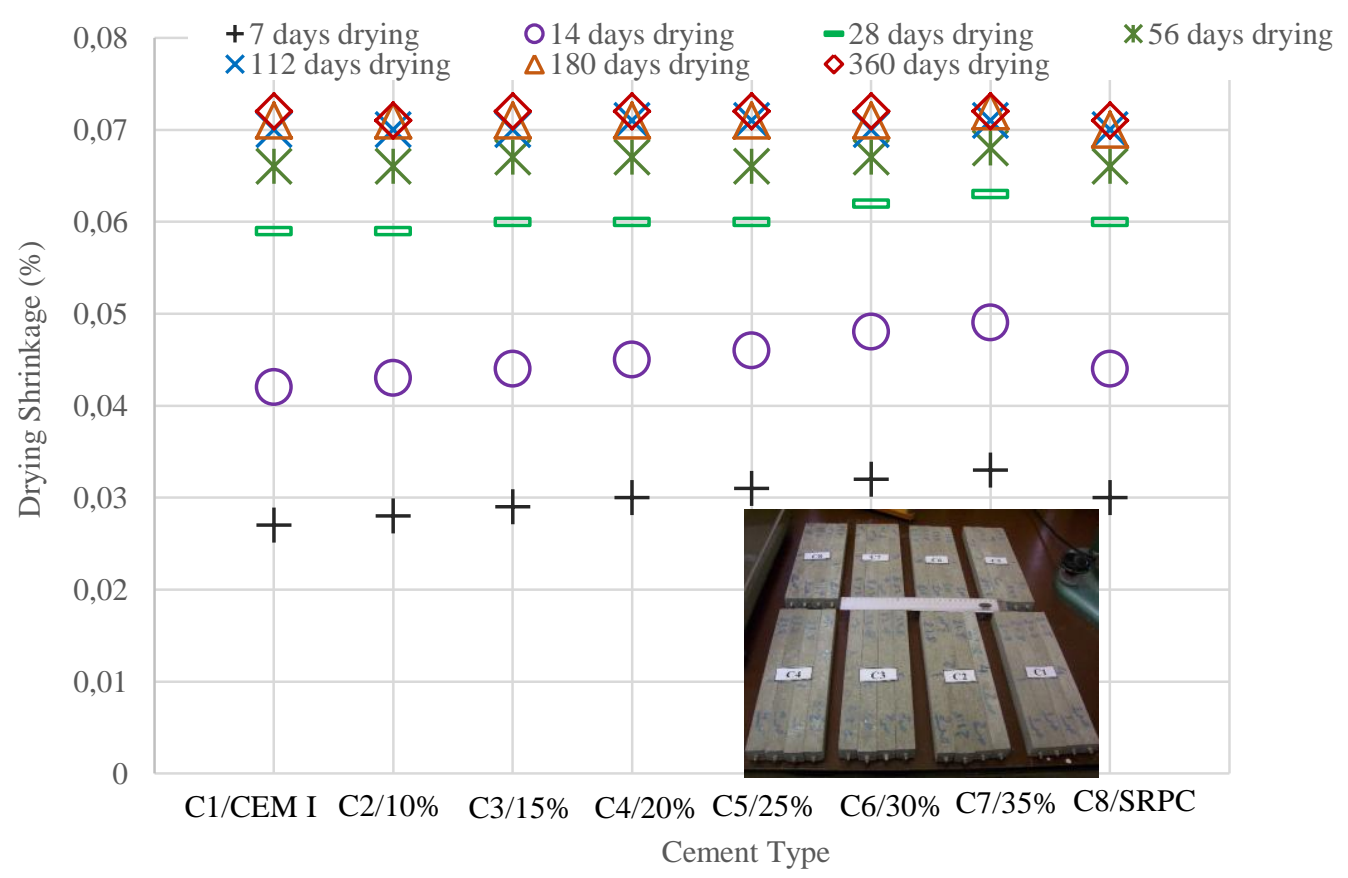

Figure 7. Drying shrinkage values of prismatic mortar specimens

\section{Conclusion}

From the experimental results, the following conclusions could be drawn:

- The studied volcanic scoria is a suitable material to be used as a natural pozzolan. It satisfied the ASTM and EN requirements for such a material. The physical properties of binders containing scoria are also in conformity with the standards requirements.

- The compressive strength of mortars containing scoria-based binders was lower than that of plain cement mortar at all ages of mortar in this study. At early ages, the mortars containing CEM II/B-P binder types had compressive strengths much lower than that of plain cement mortar. However, at 90 days curing, the compressive strengths of blended cement mortars are comparable to those of plain cement mortar. 
- Based on the results, blending CEM I of $6 \% \mathrm{C}_{3} \mathrm{~A}$ content, with $25 \%$ scoria content or more resulted in a performance similar to that of SRPC under sulphate attack. An enhanced sulphuric acid resistance was obtained as well.

- Adding scoria as a cement replacement reduced the expansion of the mortar bars exposed to sodium sulphate solution. More reduction occurs with increasing the replacement level.

- The drying shrinkage of mortar bars increases with an increase in the scoria content, especially at the early ages of drying.

- The long-term drying shrinkage of mortar bars at 360 days of drying is not affected significantly with the addition of scoria as a cement replacement, particularly with up to $25 \%$ scoria content.

- Based on the results obtained, it is recommended that scoria can be used up to $25 \%$ as a partial substitute for Portland cement in the production of blended cements. This addition ratio can reduce the quantity of $\mathrm{CO}_{2}$ released by Syrian cement plants, and the consumed energy. So, production of a green concrete could be promoted.

\section{Acknowledgement}

The authors gratefully acknowledge the technical and financial support of this research from the management of General Organization for cement \& Building Materials/Adra Cement Plant. Thanks are also expressed to Eng. Amjad Bernieh (Lafarge Co.) and Prof. Tamer al-Hajeh, vicepresident of AIU for their appreciated help.

\section{References}

[1] ACI Committee 201 (1991), "Guide to durable Concrete", ACI Materials Journal 88, 551.

[2] ACI 363R (1992), State of the art report on high strength concrete, American Concrete Institute, Detroit.

[3] Al-Amoudi, O. S. B. (2002), "Attack on plain and blended cements exposed to aggressive sulfate environments", Cement and Concrete Composites 24, 304-316.

[4] Al-Dulaijan, S. U., Maslehuddin, M., Al-Zahrani, M. M., Sharif, A. M., Shameem, M. and Ibrahim, M. (2003), "Sulfate resistance of plain and blended cements exposed to varying concentrations of sodium sulfate", Cement and Concrete Composites 25, 429-437.

[5] Al-Swaidani A. M., Aliyan S. D., Ismat R., Diyam E. and Adarnaly N, (2015), "Influence of curing time on some durability-related properties of concrete containing volcanic scoria as cement replacement", $13^{\text {th }}$ Arab Structural Engineering Conference, University of Blida, Algeria, Dec. 13-15. Accepted full paper.

[6] Attiogbe, E. K. and Rizkalla, S. H. (1988). "Response of Concrete to Sulfuric Acid Attack", ACI Materials Journal 85, 481-488.

[7] Aydın, S., Yazıcı, H., Yigiter, H. and Baradan, B. (2007), "Sulfuric acid resistance of highvolume fly ash concrete", Building and Environment 24, 717-721.

[8] Barr, B., Hoseinian, S. B. and Beygi, M. A. (2003), "Shrinkage of concrete stored in natural environments", Cement and Concrete Research 25, 19-29.

[9] Biczok, I. (1967), Concrete Corrosion and Concrete Protection, Chemical Publishing Co. Inc., New York. 
[10] Cao, H. T., Bucea, I., Ray, A. and Yozghatlian, S. (1997), "The effect of cement composition and $\mathrm{pH}$ of environment on sulfate resistance of Portland cements and blended cements", Cement and Concrete Composites 19, 161-171.

[11] Cavdar, A, and Yetgin, S. (2007), "Availability of tuffs from northeast of Turkey as natural pozzolans on cement, some chemical and mechanical relationships", Construction and Building Materials 21, 2066-2071.

[12] Fattuhi, NI., and Hughes, BP. (1988), "SRPC and modified concretes subjected to severe sulphuric acid attack", Magazine of Concrete Research 40, 159-166.

[13] General Establishment for cement \& Building Materials (www.cemsyria.com). Accessed on 10.02.2013 (in Arabic).

[14] General Establishemnt of Geology and Mineral Resources in Syria (2007), Official document nr. 3207/T/9. (in Arabic)

[15] General Establishment of Geology and Mineral Resources in Syria (2011), A Guide for mineral resources in Syria. (in Arabic)

[16] Ghrici, M. Kenai and S., Meziane, E. (2006), "Mechanical and durability properties of cement mortar with Algerian natural Pozzolana", Journal of Material Science 41, 69656972.

[17] Gonzalez, M. A. and Irassar, E. F. (1997), "Ettringite formation in low C3A Portland cement exposed to sodium sulfate solution", Cement and Concrete Research 27, 10611072.

[18] Haque, M. N. and Kayali, O. (1998), "Properties of high strength concrete using a fine fly ash", Cement and Concrete Research 28, 1445-1452.

[19] Hossain, K. M. A. (2009), "Resistance of scoria-based blended cement concrete against deterioration and corrosion in mixed sulfate environment", Journal of Materials in Civil Engineering, ASCE 21, 299-308.

[20] Irassar, E. F., Gonzalez, M. A. and Rahhal, V. (2000), "Sulfate resistance of type V cements with limestone filler and natural pozzolan", Cement and Concrete Composites 22, 361-368.

[21] Itim, A., Ezziane, K. and Kadri, E. H. (2011), "Compressive strength of mortar containing various amounts of mineral additions", Construction and Building Materials 25, 36033609.

[22] Lawrence, C. D. (1990), "Sulfate attack on concrete", Magazine of concrete Research 42, 249-264.

[23] Massazza, F. and Costa, U. (1979), "Aspects of the pozzolanic activity and properties of pozzolanic cements.” II Cemento, 76, 3-18.

[24] Massazza, F. (1993), "Pozzolanic cements", Cement and Concrete Composites 15, 185214.

[25] Massazza, F. (2006), "Pozzolana and pozzolanic cements", In Lea's Chemistry of cement and concrete, edited by P. C. Hewlett, Fourth edition, Elsevier.

[26] Meddah, M. S. and Tagnit-Hamou, A. (2009), "Effect of mineral admixtures on hrinkage measured on massive concrete elements", In Creep, Shrinkage and Durability Mechanics of Concrete and Concrete Structures-Tanabe et al. (eds), Taylor \& Francis Group, London. 
[27] Mehta, P. K. (1981), "Studies on blended Portland cements containing Santorin earth", Cement and Concrete research 11, 507-518.

[28] Mehta, P. K. (1987), "Pouzzolanes naturelles”, In Matériaux complémentaires en cémentation pour le béton, edited by V. M. Malhotra, CANMET.

[29] Mehta P. K. and Monteiro P. J. M. (2006), Concrete: Microstructure, properties, and Materials." 3rd edition, McGraw-Hill.

[30] Mindess, S., Young, J. F. and Darwin, D. (2003), Concrete, $2^{\text {nd }}$ Edition, Prentice Hall.

[31] Monteny J. E., De Belie N., Vincke E., Verstraete W. and Taewe L. (2001), "Chemical and Microbiological Tests to Simulate Sulfuric Acid Corrosion of Polymer-Modified Concrete", Cement and Concrete Research 31, 1359-1365.

[32] Monteny J. E., Vincke A., Beeldens A., De Belie N., Taerwe L. and Van Gemert D. (2000), "Chemical, Microbiological, and In Situ Test Methods for Biogenic Sulfuric Acid Corrosion of Concrete", Cement and Concrete Research 30, 623-634.

[33] Neville, A. M. (2011), Properties of concrete. Fifth edition, Pearson Education.

[34] Pavlik, V. (1994). "Corrosion of hardened cement paste by acetic and Nitric acids; Part II: Formation and chemical composition of the corrosion products layer", Cement and Concrete Research 24, 1495-1508.

[35] Ramezanianpour, A. A., Mirvalad, S. S. Aramun, E. and Peidayesh, M. (2010), "Effect of four Iranian natural pozzolans on concrete durability against chloride penetration and sulfate attack", In proceedings of the $2^{\text {ed }}$ international conference on sustainable construction materials and technology, 28-30 June, Ancona, Italy, edited by P. Claisse et al.

[36] Rao, G. A. (2001), "Long-term drying shrinkage of mortar-influence of silica fume and size of fine aggregate", Cement and Concrete Research 31, 171-175.

[37] Rodriguez-Camacho, R. E. and Uribe-Afif, R. (2002), "Importance of using natural pozzolans on concrete durability", Cement and Concrete Research 32, 1851-1858.

[38] Senhadji, Y., Escadeillas, G., Khelafi, H., Mouli, M. and Benosman, A. S. (2012), "Evaluation of natural pozzolan for use as supplementary cementitious material", European Journal of Environmental and Civil Engineering 16, 77-96.

[39] Shannag, M. J. and Yeginobali, A. (1995), "Properties of paste, mortars and concretes containing natural pozzolan”, Cement and Concrete Research 25, 647-657.

[40] Skalny, J. P., Odler, I. and Marchand, J. (2002), Sulfate attack on concrete, Spon Press, New York.

[41] South, W. (2009), A study of the compressive strength and drying shrinkage of cementitious binders prepared using natural pozzolans, $\mathrm{PhD}$ Thesis, University of Wollongong, Australia.

[42] Tangchirapat, W., Jaturapitakkul, C. and Chindaprasirt, P. (2009), "Use of palm oil fuel ash as a supplementary cementitious material for producing high-strength concrete", Construction and Building Materials 23, 2641-2646.

[43] Touttanji, H. A. and Bayasi, Z. (1999), "Effect of curing procedures on the properties of silica fume concrete", Cement and Concrete Research 29, 497-501.

[44] Turanli, L., Uzal, B. and Bektas, F. (2005), "Effect of large amounts of natural pozzolan addition on properties of blended cements", Cement Concrete Research 35, 1106-1111. 